\title{
Effectiveness of different insecticides against sucking pests in brinjal
}

A.A. SHAIKH, J.B. BHUT* AND M.V. VARIYA

Main Vegetable Research Station, Anand Agricultural University, ANAND (GUIJARAT) INDIA

\begin{tabular}{|c|c|}
\hline ARITCL & INFO \\
\hline Received & : 21.04.2014 \\
\hline Revised & : 27.07.2014 \\
\hline Accepted & : 13.08 .2014 \\
\hline
\end{tabular}

KEY WORDS :

Effectiveness, Insecticides, Sucking pests, Avoidable losses

*Corresponding author: Email: jignesh1315@gmail.com

\begin{abstract}
An experiment was conducted to study the bio-efficacy of nine different insecticides (triazophos $0.08 \%$, imidacloprid $0.002 \%$, profenophos $0.05 \%$, diafenthiuron $0.05 \%$, clothianidin 0.025 $\%$, cartap hydrochloride $0.05 \%$, thiamethoxam $0.025 \%$, thiacloprid $0.012 \%$ and spiromesifen $0.024 \%$ ) again sucking pests viz., jassid and whitefly in brinjal (GBH 1) at Main Vegetable Research Station, Anand Agricultural University, Anand during Rabi season of 2011-12. Among different insecticides evaluated, thiamethoxam, diafenthiuron and thiacloprid emerged as most effective; profenophos, clothianidin and imidacloprid were mediocre; while cartap hydrochloride, spiromesifen and triazophos were found least effective against jassid. So far whitefly is concerned, spiromesifen, diafenthiuron and triazophos emerged as most effective; imidacloprid, profenophos and cartap hydrochloride as mediocre, while clothianidin, thiamethoxam and thiacloprid emerged as least effective. Diafenthiuron exhibited significantly higher brinjal fruit yield ( $350.57 \mathrm{q} / \mathrm{ha})$, whereas triazophos and cartap hydrochloride hosted significantly lower fruit yield. The minimum and maximum per cent avoidable losses were recorded in diafenthiuron (0.00) and control (55.25), respectively. The highest Net ICBR (71.83) was obtained from the plots treated with profenophos followed by thiacloprid (56.10), cartap hydrochloride (43.93), imidacloprid (39.10) and diafenthiuron (27.69).
\end{abstract}

How to view point the article : Shaikh, A.A., Bhut, J.B. and Variya, M.V. (2014). Effectiveness of different insecticides against sucking pests in brinjal. Internat. J. Plant Protec., 7(2) : 339-344. 